\title{
The Relationship between Father Involvement and Paternal Emotion Socialization
}

\author{
Kayla E. Forshee
}

Follow this and additional works at: https://researchrepository.wvu.edu/etd

\section{Recommended Citation}

Forshee, Kayla E., "The Relationship between Father Involvement and Paternal Emotion Socialization" (2017). Graduate Theses, Dissertations, and Problem Reports. 5613.

https://researchrepository.wvu.edu/etd/5613

This Thesis is protected by copyright and/or related rights. It has been brought to you by the The Research Repository @ WVU with permission from the rights-holder(s). You are free to use this Thesis in any way that is permitted by the copyright and related rights legislation that applies to your use. For other uses you must obtain permission from the rights-holder(s) directly, unless additional rights are indicated by a Creative Commons license in the record and/ or on the work itself. This Thesis has been accepted for inclusion in WVU Graduate Theses, Dissertations, and Problem Reports collection by an authorized administrator of The Research Repository @ WVU. For more information, please contact researchrepository@mail.wvu.edu. 


\title{
The Relationship between Father Involvement and Paternal Emotion Socialization
}

\author{
Kayla E. Forshee \\ Thesis submitted \\ to the College of Education and Human Services \\ at West Virginia University \\ in partial fulfillment of the requirements for the degree of \\ Master of Arts in \\ Educational Psychology/ Child Development and Family Studies
}

Amy Root, Ph. D., Chair

Jessica Troilo, Ph. D.

Suzanne Hartman, Ph. D.

Department of Learning Science and Human Development

\author{
Morgantown, West Virginia \\ 2017
}

Keywords: fathers, involvement, emotions, socialization

Copyright 2017 Kayla Forshee 


\title{
ABSTRACT \\ The Relationship between Father Involvement and Paternal Emotion Socialization
}

\begin{abstract}
Kayla Forshee
The purpose of this study was to examine the relationship between father involvement and emotion socialization. Fathers amount of time and quality of paternal involvement (e.g., engagement in childcare activities, secondary activities, and time spent in children's company) with their preschool aged children was assessed to determine if it influenced how fathers respond to the children's emotion (e.g., disappointment, anger, and anxiety). Heterosexual fathers ( $\mathrm{M}=$ 39.46 yrs.) of children ages 3-5 years old were recruited from preschools and daycares in the larger metropolitan, D.C. area. Paternal self-report measures were used to measure father's involvement and their socialization strategies. Results showed that fathers that spend most of their time engaging recreational and leisure activities with their preschool aged child are more likely than fathers that engage primarily in childcare activities to respond to children's displays of anger with reasoning strategies. Thus, indicating that there may be a link between the quality of time fathers spend with their preschool age children and how they respond to their negative emotions. This study provides implications for future studies examining the relations between father involvement and emotion socialization.
\end{abstract}


Table of Contents

Abstract ........................................................... ii

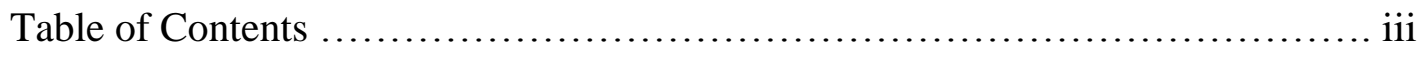

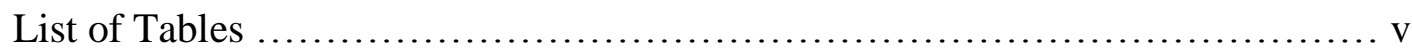

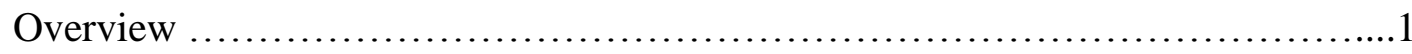

Statement of the Problem...........................................

Purpose of the Study..............................................

Literature Review .......................................................

The Role of a Father............................................. 3

Relation between Father Involvement and Parenting....................6

Paternal Emotion Socialization.......................................9

Current Study........................................................ 13

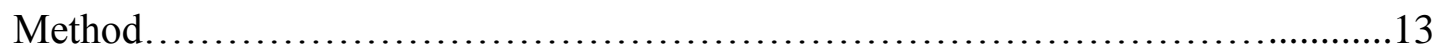

Participants................................................... 13

Measures........................................................14

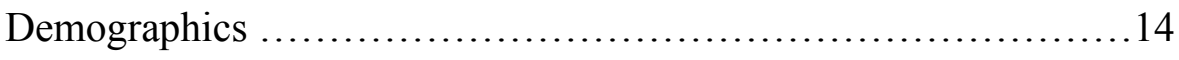

Father Involvement.......................................14

Emotion Socialization.........................................15

Procedure............................................................. 17

Data Analytic Plan......................................................18

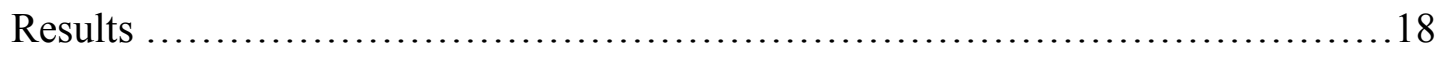

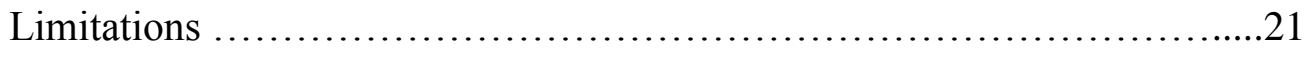

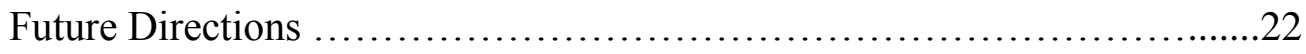

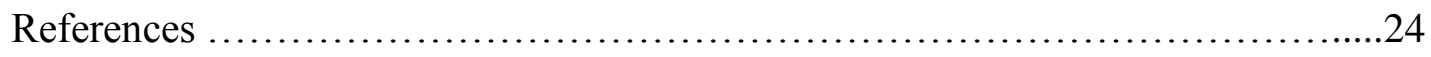


Appendix A............................................................ 33

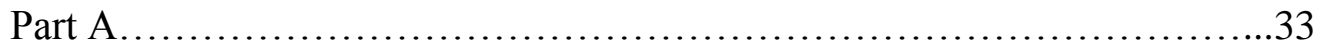

Part B...................................................... 34

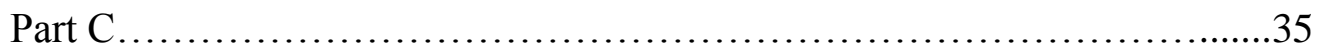

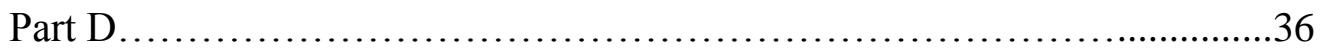

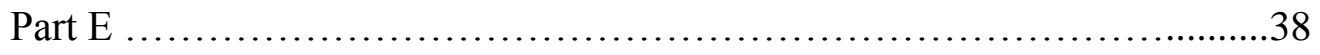

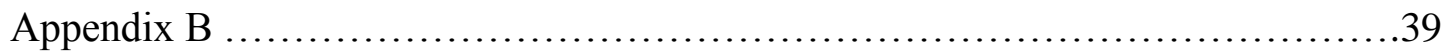

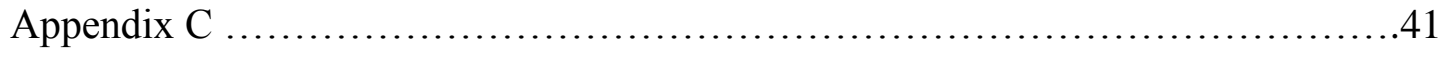

Appendix D ............................................................. 50 
List of Tables

1. Descriptive Statistics for all Variables of Interest...............................28

2. Correlations between Fathers Involvement Codes.................................

3. Correlations between Total Involvement, Primary Involvement, and Company

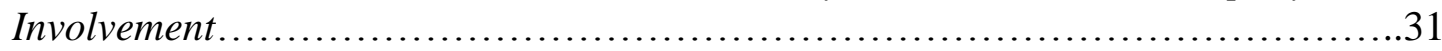




\section{Overview}

Fathering is a concept that has been relatively understudied. The concept of fathering and how fathers are involved with their children has changed throughout the years (Craig, Powell, \& Symth, 2014). The role a father plays is often dependent on an individual father's perception of what it means to be a father. Morman and Floyd (2006) found that some fathers view the characteristics of a good father as emotional and relational (e.g., love, availability, role modeling, providing, and involvement). Fathers' views of fatherhood likely impact how they interact with their children. Belsky (1984) proposed a model that implies that it is parental determinants that influence the way parents socialize their children. Per this theoretical perspective, it is likely that paternal perspectives are related to a father's involvement with their children, and that involvement is related to parenting practices.

The interactions between fathers and children lay the foundation for the father-child relationship. The significance of supportive parenting interactions can be drawn from attachment theory. Bowlby (1969/1982) explained that attachment-caregiving social bonds were created via parent-child interactions, and it is within these interactions that parental behavioral systems are activated. When these systems are activated fathers often respond to children in different ways depending on the context of the situation. Paternal sensitive responding is important for building a secure attachment relationship; in turn, the attachment relationship between father and child is related to the development of children's self-concept, personality, peer competence, and emotion regulation (Kerns, 2008). Therefore, it is important to gain a better understanding of the aspects of what makes a father respond sensitively or insensitively. The quality and characteristics of fathers' parenting behaviors are related to the father-child attachment relationship. Brown, Mangelsdorf, and Neff (2012) found that fathers who were highly involved and were sensitive to their children were shown to have children with secure attachments to them, thus reinforcing the idea that involvement and sensitive parenting behaviors influence outcomes of secure attachment relationships.

In addition, the quality of paternal involvement has been shown to be linked to the quality of parental behaviors. Grossman and Volkmer (1984) found that fathers who valued the fatherchild attachment relationship had children with whom were securely attached to them and were more likely to engage in infant care. These were also the fathers that were shown to engage more 
often in play while showing consistent sensitivity to their child during play across a four-year span. Thus, indicating that the quality of involvement is related to paternal sensitivity. However, it is likely that involvement is also linked to other parenting processes, including specific socialization behavior such as emotion socialization. How fathers respond to their children's emotions is a part of how they socialize their children (Denham, Bassett, \& Wyatt, 2007).

Paternal socialization of emotion is significant in the development of children's emotional competence. For instance, Denham, and Kochanoff (2002) found that fathers contributed to their children's emotional knowledge (e.g., emotion expression understanding and emotion situation knowledge) at age four if they were largely positive in their emotions and reactions toward their children in year two. In another study, Denham, Bassett, and Wyatt (2010) also found similar findings related to the influence of paternal responding to children's emotions that provides support for the unique contributions fathers make in children's emotional competence. Thus, it seems important to better understand what characteristics impact how fathers respond to their children's emotions. A study of this nature is significant for understanding the evolving role fathers play in children's lives and for understanding the importance of father-child interactions. It will provide some insight as to why some fathers exhibit different parenting behaviors than others.

\section{Statement of the Problem}

The role father's play in children's development is a topic that is understudied, and there have been few studies that examine what may contribute to fathers' supportive or non-supportive emotion socialization. Thus, examining aspects of fathers parenting behaviors in relation to their involvement activities will play an important role in understanding how fathers socialize their children's emotions. A study of this nature can lay a foundation for further research on influences of paternal responding. This study can also be of importance for therapist working with fathers and their children. If the quality of paternal involvement is shown as an indicator of fathers' responses to children's emotions, it could possibly help therapists understand why fathers' respond the way they do, and develop inventions to bolster father-child relationships. 


\section{Purpose of the Study}

The purpose of this study was to examine the relationship between the quality and quantity of time fathers spend with their preschool aged children (type of engagement) and paternal responding to children's emotions (emotion socialization). The overarching research question is: Does the level of supportive and non-supportive socialization strategies differ based on the type of father involvement?

\section{Literature Review}

Fathering is a social construct; there are multiple societal influences that define a father's role in a child's life (Marsiglio \& Cohen, 2000). The definition of fathering, and what it means to be a father, has changed throughout history. Lamb (2000) explains that there are changing views about the father role in the family, which has evolved from fathers being "moral teachers" prior to the Industrial Revolution to "breadwinners" during the Industrial Revolution. In the 1930's and 1940's fathers' primary role was the "sex-role model" and the idea of a father evolved in the 1970 's to the idea of a father as taking on a more nurturing role. The definition of a "father" is a product of culture; therefore, the meaning of fatherhood is different for every individual, and what it means to be a good/effective father changes as cultural perspectives change (Griswold, 1993). As the role of fathers change along with cultural perspectives of fatherhood, it is important to understand the role in which fathers play in socializing their children. Research indicates that fathers are important to children's development. For instance, Easterbrooks and Goldberg (1984) concluded that sensitive fathering was essential for children's affect and task orientation. Therefore, examining the amount and quality of time fathers spend with their children, along with the implications it has for paternal responding to children's emotions is significant in understanding the evolving role fathers play in children's lives. Thus, in this study, the relation between the quality and quantity of time fathers spend with their preschool aged children and how fathers respond to their children's emotions was examined.

\section{The Role of a Father}

Prior to examining the literature on paternal responses to children's emotions, it is important to understand work on fathers' perceptions of their role in childrearing as it is logical to assume that a fathers' perceptions of fatherhood would be related to the way they engage with 
and socialize their children. Studies have shown that fathers have different views of what it means to be a father. For instance, Olmstead, Furtis, and Pasley (2009) examined 34 nonresidential fathers' perceptions of their role as a father. Participants were involved in focus group interviews, and reported that they perceived fathering as multidimensional concept with a variety of co-existing meanings and responsibilities. Specifically, seven role identities were found: provider (economic responsibility to their child), teacher (direct and indirect instruction), protector (protect their children physically and emotionally), disciplinarian (administering and enforcing rules), caretaker, supporter (being reliable and engaging in behaviors in which provide children with emotional, encouraging, and comforting support), and the co-parent (respecting, communicating and negotiating with the other parent regarding care of the children). The findings from this study established that non-residential fathers who were either married or divorced perceived their role as a father to be a teacher, a provider, and a supporter.

In a similar study, Morman and Floyd (2006) examined fathers' views of the most important characteristics of being a good father. Participants included 374 fathers and they answered an open-ended question of what they thought it meant to be a good father. Older fathers reported that forgiveness and admitting mistakes were characteristics of a good father more than younger fathers. Fathers also noted that characteristics that demonstrate the emotional and relational component of fathering, including love, availability, role modeling, involvement, and providing were aspects of being a good father. These findings indicate that a father views fatherhood as multidimensional, and that there are many characteristics that are important to being a good father. It is important to understand the different roles fathers play because these perceived roles inform the ways they engage with their children. Indeed, fathers' perceptions of what it means to be a good father likely are reflected in the ways they interact with their children, both the quality of those father-child interactions and the ways fathers engage with their children. Thus, it is likely that fathers will be involved in a variety of tasks throughout the day, and that their level of involvement will affect how they interact with their children.

Belsky (1984) provides the framework for which this study will be built upon. Belsky's Process Model as stated previously proposes that there are multiple determinants of parenting that influence the socialization of children. Based on this model, a parent's personality characteristics, children's characteristics, a parent's personal history, and culture influence how a 
parent engages with their children. Thus, from this perspective, it is likely that fathers' perceptions of what being a father means will inform how much they are involved, as well as how they interact with their child. Also, how much they are involved with and how they interact with their children will most likely be related to how they respond to their children (Easterbrooks \& Goldberg, 1996).

This study is beneficial in providing a better understanding of the factors that may influence fathers' parenting. The significance of studying supportive father-child interactions can be drawn from attachment theory, which emphasizes the role caregivers play in children's development and socialization. Ainsworth (1989) references the idea that children form "child attachments" to parents and parents form "parental bonds" to children. In his writing, Bowlby (1969/1982) described the "attachment-caregiving social bond," which was created via parentchild interactions. During these interactions parents' behavioral systems are activated to enhance child survival and reproductive fitness. When different parental behavioral systems are activated, parents may respond differently to children. Attachment to fathers affects children's development. Kerns (2008) explains that secure attachment is "related to the development of children's self-concept, emotion regulation, personality, and peer competence” (p.374).

Importantly, while attachment theory was largely founded on mother-child interactions, attachment theorists discuss the significance of fathers to children's development. For instance, Grossmann and Volkmer (1984) gathered data in Germany, Israel, and the Unites States. They found that fathers who were present for the birth of their child valued attachment with their infant. These fathers also had infants who had secure attachment relationships to them, and these fathers were more likely to participate in infant care. Two years later, these fathers were more engaged in play with their children, and paternal sensitivity to their children during play was stable across a four-year span. Moreover, fathers who were more sensitive to their toddlers represented a sensitive guide during teaching tasks when the child was 6 years old (Grossmann \& Volkmer, 1984). Taken together, the findings from this longitudinal investigation indicate that fathers' sensitive responding to children during play is a good indication of the quality of the father-child relationship. Therefore, better understanding of how paternal involvement is related to parenting practices seems important given the significant role fathers play in their children's development. 
There are other studies that link father involvement to the quality of the father-child relationship. Brown, Mangelsdorf, and Neff (2012) aimed to obtain a greater understanding of the father-child attachment relationship by examining the associations between father involvement, paternal sensitivity, and father-child attachment security. Seventy-one father-child dyads participated in this longitudinal study. Participants were assessed in two phases. Once when the child was 13 months (Time 1) and again at age 3 years (Time 2). Fathers completed questionnaires to measure paternal involvement at Time 1 that assessed their parenting responsibility and paternal sensitivity. Also, at Time 1, fathers and children were assessed via semi-structured observations to examine father-child attachment. At Time 2, father involvement was assessed via parenting responsibility questionnaire along with an in-home interview that measured accessibility and interaction forms of involvement. Paternal sensitivity was assessed using a semi-structured father-child play task. Observation methods were used to assess fatherchild attachment.

Brown, Mangelsdorf, and Neff (2012) found evidence that the quantity and quality of early fathering behaviors were related to the stability of father-child attachment security. At age 3, children exhibited more secure relationships with their fathers when fathers displayed higher levels of sensitivity and involvement, thereby providing evidence of a link between involvement and father-child relationship quality. It was also concluded that early father-child attachment relationships predict higher levels of paternal sensitivity in later childhood. Father-child attachment security when the child was 13 months was shown to predict paternal sensitivity at age 3. This is an important finding to note because it reflects how the attachment relationship can directly relate to the quality and characteristics of paternal parenting behaviors. While the significance of the attachment relationship is not a key determinant within this study, the importance of the attachment relationship is relevant. Bowlby (1982) explains that children with whom are securely attached to their fathers will exhibit behaviors that reflect a sense of trust, comfort, and emotional availability.

\section{Relation between Father Involvement and Parenting}

Research on father involvement has shown that there are different types of involvement. Lamb, Pleck, Charnov, and Levine (1985) provided insight to the father involvement construct and identified three components: accessibility, responsibility, and engagement. Accessibility 
reflects the availability of the father for the child. Responsibility includes tasks in which ensure that the child is taken care of physically and financially. The engagement construct of paternal involvement is the focus within the current study. Pleck (2012) discussed the engagement construct of involvement and defined it as direct interaction with children. It is within this construct that parent-child interactions and parenting behaviors are displayed.

Craig, Powell, and Smyth (2014) compared parental childcare time from 1992 to 2006 in Australia to determine if there has been shift toward more intensive parenting in which reflects a broader range of parent-child activities. Data was obtained from the Australian Bureau of Statistics Time Use Survey in 1992 and 2006. The sample consisted of 1,634 couple households (ages 20-59 years) that were either married or cohabitating with at least one child age 0-14. Participants were asked during the survey to complete a diary on one or two days regarding primary and secondary daily activities in intervals of five minutes. Diary responses were coded into three categories which included: childcare as a primary activity (interactive talk based activities, physical care, and transporting care), childcare as a secondary activity (supervising children without engagement), and time spent in children's company (spending time with children and engaging in leisure, community, or recreational activities).

Results showed that father's time spent with children was considerably higher in 2006 than 1992 across all categories. Fathers were shown to engage in more recreational and leisure activities with children than mothers. Moreover, in 2006, fathers spent two hours a week more on routine childcare than in 1992. Evidence also suggested that fathers engaged in less active childcare when children were older. Moreover, over time, fathers appeared to engage in a wider range of activities with their children, including hands on routine care. This change in an Australian sample provides support for the notion that fathers' involvement has likely diversified in the last 20 years, and likely impacts parenting processes in unique ways. Thus, fathers may be participating in more active ways in relation to childrearing.

There is little work examining the link between father involvement and father's parenting practices. In one study from the 1980s, the relation between father involvement and paternal parenting was examined. Easterbrooks and Goldberg (1984) explored the influence of father involvement, father characteristics, and father-child attachment on preschool aged children's development. They examined paternal attitudes, behavioral sensitivity, and father-child 
relationship quality to understand the influence it has on toddlers' affect and task orientation. Father involvement was related to the amount of play time with the child, which was a significant predictor of the time spent alone with toddler in caregiving engagement. Moreover, fathers who were warm in their interactions with their toddlers had toddlers that demonstrated high amounts of toddler autonomy (an adaptive behavior during this age period). This study offers insight regarding the link between father involvement and other parenting processes.

In a related study, Buckley and Schoppe-Sullivan (2010) examined the relation between father involvement in caregiving and play with preschool-aged children and co-parenting behaviors. Nontraditional beliefs surrounding a father's role and family earner status was also investigated to determine if they played a moderating role between father involvement with children and co-parenting behaviors. A sample consisting of 80 two-parent families were obtained. Self-report and observations were utilized for data collection. Paternal involvement in play and caregiving was evaluated based on father reports related to the frequency of engagement. Co-parenting behaviors were determined based on the participation of mother, father, and child in two observed 10-minute family tasks. Each parent reported individual selfreport questionnaires designed to log their perceptions of their partner's co-parenting behavior. Mothers and fathers also completed a self-report questionnaire regarding their attitudes surrounding father roles.

Buckley and Schoppe-Sullivan (2010) reported that in single-earner families, greater father engagement in caregiving activities was related to less supportive co-parenting behaviors and more undermining co-parenting behaviors. However, this was only true for parent's perceived co-parenting behavior and not in observed actual co-parenting behavior. In dualincome families, fathers who engaged more frequently in caregiving and play activities showed less undermining co-parenting behaviors. In addition, in dual income families, fathers were more involved in play and displayed more positive co-parenting behaviors. This study provides evidence that father involvement affects the parenting process.

In another study, Jia and Schoppe-Sullivan (2011) examined the associations between coparenting and father involvement in two-parent families with preschool aged children. Selfreport questionnaires and observations were collected at two points in time: when children were 4 and then when they were 5-years-old. Fathers' involvement in play and caregiving activities 
was assessed based on paternal reports. Specifically, fathers rated how frequently they engaged in developmentally appropriate play and caregiving activities. Supportive and undermining coparenting behaviors were also assessed via observations during an interactive family task.

Jia and Schoppe-Sullivan (2011) found that paternal involvement in caregiving and play activities predicted dimensions of co-parenting behavior (e.g., supportive and undermining behaviors); thus, there is a longitudinal pathway from father involvement to co-parenting behavior. In addition, the findings suggested that fathers' role in play leads to better parenting outcomes. Fathers that were more frequently involved in play with their children were shown to engage in more supportive and less undermining co-parenting behaviors. However, fathers who initially were more involved in more caregiving activities when children were four years old were shown to display less supportive and more undermining co-parenting behaviors a year later. This provides evidence for the idea that type of father involvement activities can have a direct impact on paternal behaviors.

\section{Paternal Emotion Socialization}

There is some evidence indicating that paternal involvement is related to general parenting processes. However, the current literature is limited in that it focuses on broad indices of parenting, when the examination of more specific aspects of socialization is examined a better understanding of the links between involvement and fathering can be seen. Indeed, Grusec and Davidov (2015) have argued that it is increasingly accepted by researchers that socialization of children is nuanced depending on the context.

One such area is the socialization of emotion, Denham, Bassett, and Wyatt (2015) state that emotion socialization is a process that leads to outcomes of emotion regulation and emotional competence. Parents play an important role in the socialization of their children's emotions through interactions with their child. Parents possess meta-emotion philosophies, or beliefs about how emotions should be expressed, how important they are, and how they should be expressed in different situations (Gottman, Katz, \& Hooven, 1997). Eisenberg, Cumberland, and Spinrad (1998) indicate that three mechanisms comprise the process of emotion socialization: modeling, contingent reactions, and teaching. These processes impact children's emotional expression, knowledge, regulation, and social functioning. Modeling is setting an example for the child via emotional or behavioral expressions. Contingent reactions are the 
supportive or non-supportive reactions parents engage in toward their children's emotions. Teaching mechanisms are used to aid children in learning about emotions. The focus of the current study is on fathers' responses to children's emotions; therefore, this type of socialization process will be the focus of the rest of the literature review.

Denham, Bassett, and Wyatt (2015) indicates that parental reactions to children's emotions impacts how a child expresses their emotions. There is empirical work that has tested the association between emotion socialization and children's outcomes. For instance, Denham, Mitchell-Copeland, Strandberg, Auerbach, and Blair (1997) examined parental emotion socialization in preschoolers, and found that parental responses to difficult child moments, matching emotions, and total emotional talk were shown to be significant predictors of children's emotional competence. Denham et al. (1997) also found significant relations between emotion socialization and children's social competence. The same pattern of results (i.e., links between responses to emotions and children's socio-emotional development) have been reported elsewhere (Denham \& Grout, 1992; Fabes, Poulin, Eisenberg, \& Madden-Derdich, 2002; Spinrad, Stifter, Donelan-McCall, \& Turner, 2004).

Thus, parents' reactions help children to understand how to appropriately express certain emotions and when emotions should be expressed. The majority of literature on emotion socialization has focused mothers' responses to children's emotions, but there are some studies examining paternal emotion socialization. For instance, Denham and Kochanoff (2002) provide a direct indication of how father's emotion socialization impacts children's emotional competence. They examined paternal socialization contributors to their young children's emotional knowledge. Emotion modeling, responding, and teaching were the three socialization contributors examined. They found that paternal socialization of emotion predicted only some aspects of their 4-year-olds emotional competence. When fathers were largely positive in their emotions and reactions to children's emotions in year 2, their own negative emotions and reactions in year 2 negatively contributed to children's emotion knowledge (emotional expression understanding and emotional situation knowledge) at age 4. Thus, these finding indicate the impact that fathers can have on their children's emotion socialization. Their socialization tactics can have an effect on children's emotional competence. This study also 
reinforces the idea that father's positive emotional displays and responding can help their children display emotions in appropriate ways.

There have also been some studies examining fathers' emotion socialization practices in relation to mothers' emotion socialization practices. For instance, Blandon (2015) explored the differences in mothers' and fathers' responses to their younger and older children's negative emotions. They reported that mothers provided more supportive reactions to their children's emotions than fathers. Moreover, fathers responded more negatively than mothers when reacting to older children's negative emotions. Blandon (2015) indicated that it is possible that fathers may often disapprove of negative expression of emotion because they anticipate that their older children are more skilled at handling their negative emotions consistent with family rules.

Kennedy-Root and Rubin (2010) also investigated the differences between mothers and fathers in the socialization of preschool aged boys' and girls' emotions. The purpose was to examine emotion socialization strategies related to the gender of the parent and child. The sample consisted of 125 parents of preschool aged children ages 3-5. Participants included only heterosexual parents living in the same household and parents only reported based on biological children. Kennedy-Root and Rubin (2010) utilized self-report questionnaires as a method for data collection.

Their results provide an indication that mothers and fathers reactions to daughters and sons same emotions are different. Mothers reported responding with a happier response to daughter's displays of happiness than fathers reported regarding the same emotional expression as their sons and daughters. In regards to responses related to children's displays of anxiety, fathers reported responding to boys displays of anxiety with surprised emotions. Fathers also reported that they would often respond to son's anxiety displays with more supportive and acknowledging responses. Fathers also reported feelings of disgust in relation to their son's displays of disappointment. These findings indicate that mothers and fathers differ when responding to children's displays of emotion.

Denham, Bassett, and Wyatt (2010) also examined gender differences of parents in the socialization of emotion in their preschool aged sons and daughters. Eighty preschoolers and their parents participated, and completed questionnaires and an observational session. They reported significant gender differences in parents' socialization. Fathers observed expressive 
balance (scores created of fathers' overall emotional expressions exhibited during an interaction with their child) was greater for fathers than mothers. Fathers were shown to discuss emotions more often with daughters than sons. Fathers' responding was also positively predictive of children's emotional competence in kindergarten. Fathers observed and self-reported emotions and reactions to children's emotions predicted preschooler's emotional knowledge. Especially for girls, paternal self-reports of emotions and reactions positively predicted children's later displays of emotional rule knowledge. Fathers that report or show positive emotions toward their children's emotions may help lay a secure emotional foundation for children to build off of. Denham, Bassett, and Wyatt (2010) explain that this may be because parents' positive emotional styles may have created a foundation for children to use distraction to maintain emotions. Thus, it seems that fathers contribute to their children's emotional development, and some of these contributions may be unique (i.e., different from mothers' contributions).

There are, however, few studies examining what may contribute to fathers' supportive or non-supportive emotion socialization. In one study, Blandon (2015) provided evidence for some of the antecedents of emotion socialization. Fathers with higher baseline RSA (indicating more emotion regulation) reported using more supportive behaviors; however, there was only a positive association for older children's emotions. This result indicates that father's physiological regulation may enable adaptive parenting during situations that are emotionally significant. This is a good indication that the role father's play, their characteristics, and their paternal perceptions may be significant to their responses to their children's negative emotions.

A study of this nature is significant to the understanding of antecedents that impact fathers' responses to their children's emotions. Upon a reflection of the literature, it is likely that there will be a relationship between the quality of time fathers spend with their children, and how fathers respond to their preschool aged children's' emotions. As seen in the study by Easterbrooks and Goldberg (1984), the amount of father involvement was related to parenting. Thus, it is possible that these relations also exist regarding emotion socialization, and it is possible that the relations may change when examining the quality of father involvement (e.g., engagement). Gaining an understanding of the reasoning behind how fathers to respond to children's emotions will contribute to an overall better understanding of how fathers contribute to children's development. The quality of emotion socialization has implications for children's 
development of emotional competence and social competence (Denham et. al., 1997; Denham \& Kochnoff, 2002). Not only is a study of this nature useful for a better understanding of fathers' impact on children's development, the quality and type of paternal responding also contributes to the father-child attachment relationship, which is also an important aspect to examine in relation to fathers' role in children's lives.

\section{Current Study}

In the current study, the relation between types of involvement and paternal emotion socialization was examined. Fathers recorded the types of activities they engaged in with their child on a typical weekly basis. These activities were coded via a revised version of the types of involvement described by Craig et al. (1992; see definitions listed above). This resulted in the creation of three groups of fathers: fathers who spend the majority of their time in childcare as a primary activity (childcare-primary group); fathers who spend the majority of their time in childcare as a secondary activity (childcare-secondary group), and fathers who spend the majority of their time in children's company (child company group). These three groups were compared on the level of fathers' self-reported supportive and non-supportive emotion socialization strategies. Thus, the overarching research question is: Does the level of supportive and non-supportive socialization strategies differ based on the type of father involvement? The following hypotheses will be tested:

1. The childcare-primary group will demonstrate higher levels of non-supportive emotion socialization strategies and lower levels of supportive emotion socialization group than the child company group. This is based on the notion that fathers' beliefs about their role in childcare will influence how they interact with their children (Morman \& Floyd, 2006). Better put, if fathers view their primary role in their child's life as meeting their children's basic needs, they may not prioritize emotion socialization, thus resulting in higher levels of non-supportive responses.

\section{Method}

\section{Participants}

The sample used consisted of 46 fathers of preschool aged children (child age $-M=$ 3.87 ; $\mathrm{SD}=.79$; range $3-5$ years). The sample was restricted to heterosexual fathers in which 
reported on biological children only; no siblings were included within this study. The sample was drawn largely from preschools and daycare centers in and around the greater Metropolitan Washington, DC area. The average age of fathers was 39.46 years ( $\mathrm{SD}=7.16$; range 22-58 years). Sixty-four percent of fathers within the sample were Caucasian-American; 6 percent were Latino-American/Hispanic American, 19 percent were African American, and 11 percent were Asian-American. Lastly, most fathers had received a college/university degree (48.9\% completed graduate degree; $14.9 \%$ had some graduate schooling; $19.1 \%$ had obtained a college/university degree; $8.5 \%$ had taken some college/university courses; $2.1 \%$ had completed a vocational school).

\section{Measures}

Demographics. To obtain demographics of the fathers, fathers completed a demographic questionnaire (Appendix A). The self-report questionnaire consisted of five questions regarding paternal age, ethnicity, education level, occupation, other persons living in their home, and approximate number of hours spent with their preschool aged child daily.

Father involvement. To assess the amount and quality of time fathers spend with their preschool aged children, paternal self-report time diaries were examined (Appendix B). Fathers reported the amount of time spent with the child along with the activities they engaged in with their child on a weekly basis. For coding purposes a revised version of Craig, Powell, and Smyth (2014) diary coding system was used. Father responses were separated into categories to assess the quality of time fathers spend with their children. The four categories created consist of: Childcare as a Primary Activity, Childcare as a Secondary Activity, Time Spent in Child's Company, and Mixed Responses. Childcare as a primary activity consisted of responses related to interactive talk based activities, physical care, and accompanying care. Childcare as a secondary activity consisted of responses related to supervising children without engagement such as sports practices or playdates. Time spent in children's company categorized all responses reflecting recreational and leisure activities along with social and community activities. Responses that reflected multiple categories were placed in the mixed category. For this study, responses related to childcare as a primary activity along with time spent in children's company were targeted. Reliability was coded on $10 \%$ of the sample by a second coder, the percent agreement across the two coders was $86 \%$. 
Emotions socialization. Participating fathers completed the Emotion Stories Questionnaire (Appendix C). A series of vignettes used by Mills and Rubin (1990) in previous studies at the University of Waterloo were included in this questionnaire. These vignettes have been administered in past research (e.g., Henderson, 1996; Kennedy, 2006; Kennedy Root \& Rubin, 2010). Each of these stories portrays a child experiencing one of four emotions (happiness; anxiety; anger; or disappointment) at home or with his/her father in public. It was requested that fathers imagine that the protagonist in the story was his child. Fathers were asked to answer two questions after reading each vignette. The first question asked, "How would you feel if you saw your child act in this manner? "Fathers were asked to rate on a five-point scale regarding emotions of anger; disgust; embarrassment; anxiety; happiness, and sadness with 1 indicating "Not at all" and 5 indicating "Extremely". The second question fathers were asked to respond to was "What, if anything, would you do in response to your child displaying happiness/ anxiety/ anger/ disappointment just in front of you/ in front of others. For this study, the second question responses were targeted.

Emotion story coding. Responses were coded using a scheme developed by Mills and Rubin (1990) (Appendix D). This method has been used in previous studies of emotion socialization (e.g., Henderson, 1996; Kennedy, 2006; Kennedy Root \& Rubin, 2010). This coding scheme classifies responses into a total of twenty-one specific categories. Within each story, each category was coded as either present in (1) or absent from (0) the rater's (either mother or father) report of his/her behavior. The categories are Does Nothing (purposefully ignores child's behavior or emotional expression); Direct Command-Behavior (With reference to child's behavior, parent makes a verbal command using imperative speech forms.); Direct Command-Feelings (With reference to child's expression of emotion parent makes a verbal command using an imperative speech form); Indirect Command-Behavior (With reference to child's behavior, parent makes a verbal command using a polite speech form (deferential, interrogative, or passive forms), Indirect Command-Feelings (With reference to child's expression of emotion parent makes a verbal command using a polite speech form (deferential, interrogative, or passive forms); Question Situation (Parent asks a question or initiates a conversation in order to better understand the child's perception/understanding of the situation.), Question Feelings (Parent asks a question or initiates a conversation in order to better understand child's feelings.), Support-Acknowledge Behavior (Parent encourages, supports, reassures or 
shows appreciation for child.), Support-Acknowledge Feelings (Parent encourages, supports, reassures or shows appreciation for child's expressed feelings, emotions, or state.); Affection/Comfort (Parent expresses affection either physically or verbally.); Praise Child (Parent positively evaluates child's behavior, including emotional expression.); Praise Behavior (Parent positively evaluates child's character or personality); Punishment (Parent imposes a negative consequence or threatens to do so on child's behavior or emotional expression.); Criticize Behavior (Parent negatively evaluates her child's behavior.); Criticize Child (Parent negatively evaluates child's character or personality.); Modeling (Parent demonstrates appropriate behavior to child, with the possibility of teaching or training child.); Reasoning (Parent explains why child should behave a certain way or points out the natural consequences of child's behavior.); Other-Oriented Reasoning (Parent explains why the child's behavior is right or wrong by pointing out the consequences of their behavior for another person or makes child aware of another's point of view, state of mind and/or emotions.); Guidance/Pragmatic Solutions (Parent suggests how the present situation could be solved or handled differently in order to prevent similar situation from occurring again.); Indirect Intervention (Parent joins child in trying to solve problem or work through the situation.); and Direct Intervention (Parent intervenes or resolves situation without involving child in the process).

The codes were summed and proportionalized due to variation across participants in the total number of strategies reported. For instance, a parent could respond with a single strategy (e.g., "I would pick him up and leave the store.") or multiple strategies (e.g., "I would ask him what happened and then give him a hug.") for the same story. The codes were proportionalized as follows: (1) sum of codes across all stories by total number of strategies across all stories; (2) sum of codes across stories of a single emotion type (e.g., children's display of happiness) by total number of strategies for stories of a single emotion type; and (3) sum of codes across stories of a single context (e.g., public) by total number of strategies for stories of a single context.

\section{Data Reduction.}

The total codes were reduced to four factors based on previous research (Henderson, 1996). The factors were as follows: directiveness (direct command behavior + punishment); intervention (direct intervention + indirect intervention + guidance/pragmatic solutions); reasoning (indirect command behavior + question situation + reasoning + other oriented reasoning), and warmth (support/acknowledge behavior + affection/comfort + praise behavior + 
support/acknowledge feelings). These factors were used for each emotion as per previous research (Kennedy Root \& Rubin, 2010). Therefore, there were a total of 12 dependent variables (e.g., directiveness - disappointment; directiveness - anger; directiveness - anxiety; intervention - disappointment; intervention - anger; intervention- anxiety; reasoning - disappointment; reasoning - anger; reasoning - anxiety; warmth - disappointment; warmth - reasoning; warmth - anxious).

\section{Reliability.}

Mothers' and fathers' responses to the questions "What, if anything, might you do in response to your child displaying (happiness/anxiety/anger/disappointment) in (front of others/just in front of you) were coded by a single coder. Coders were blind to the gender of the parent reporter and, when possible, child gender. Coders were not always blind to child gender because parents often used pronouns, such as "he" and "she" in their responses. A second rater was trained to use the coding scheme. Following reliability training, the second rater coded a randomly selected group of 20 responses ( $22 \%$ of the sample) to calculate inter-rater reliability. Cohen's Kappa was .83 over all codes.

\section{Procedure}

The data was drawn from archival data that was collected from 2004-2006 in the Metropolitan Washington, DC area as part of a larger study on emotion socialization. Distribution of recruitment letters in preschools and daycare centers were used to contact potential participants. The scope and significance of the project was explained in the initial recruitment letter. Also, included in the recruitment letter was a Participant Information Form for interested fathers to return if they were interested in participating in the study. Once fathers agreed to participate, packets were either mailed to their home or distributed within the preschool classroom or daycare center. Packets included: (1) the Statement of consent; (2) Demographic questionnaire; (3) Father Involvement time diary, and (4) the Emotion Socialization Questionnaire. A cover letter was also attached instructing fathers to complete the questionnaire in a private space where they will not be disrupted. 


\section{Data Analytic Plan}

Prior to all analyses, various diagnostic analyses (e.g., distributions, outliers) and missing data analyses was conducted. All data was examined for distribution and outliers, and appropriate transformations have been applied as needed. To test the hypothesis, two groups were formed: one group was higher in father involvement coded as primary; and one group was higher in father involvement coded as company. To maximize the sample size, the groups were formed simply by having the high primary group consist of those fathers who spent more time in primary activities relative to company activities; the high company group was those fathers who spent more time in company activities relative to primary activities. The two groups were compared in relation to the following: directive, intervention, reasoning, and warm responses to children's emotions. Reasoning, warmth, and intervention strategies are typically regarded as supportive responses to emotions; and directiveness is typically regarded as a non-supportive response in which was the case for this study.

\section{Results}

First, descriptive statistics and correlations were conducted with all variables of interest (see Tables 1-3). As noted in Table 2, the total involvement score was positively related to all the involvement codes, and significantly and positively to the primary and company codes. When the correlations between the involvement codes and the emotion socialization codes were examined, there were several significant associations. Some, but not all, of the emotion socialization codes were correlated with one another (see Table 3). For instance, all of the directiveness codes (e.g., directiveness to anger, directiveness to disappointment, and directiveness to anxiety) were all significantly and positively correlated. Directiveness to anger was positively correlated to directiveness to children's anxious emotions and to directiveness to children's disappointment. There was also a significant, positive relationship between directiveness to anxiety and directiveness to disappointment. Similarly, intervention to anger and intervention to disappointment were significantly and positively correlated. Also, intervention in response to disappointment was also positively and significantly related to intervention in response to anxiety. Intervention in response to anger was negatively and significantly related to reasoning in response to anxiety 
Reasoning in response to disappointment was positively and significantly related to reasoning in response to anxiety. Warmth in response to anger was positively and significantly related to intervention in response to anger. Moreover, warmth to disappointment was positively and significantly associated with warmth to anger. Interestingly, there were significant, negative relation between warmth and reasoning. Specifically, warmth as a response to anxiety was negatively significant to reasoning as a response to anxiety. Warmth as a response to anger was negatively and significantly related to reasoning as a response to anxiety. Warmth as a response to disappointment was negatively significant to reasoning as a response to disappointment. Also, as shown in Table 3, another negatively significant finding was found between reasoning to disappointment and directiveness to disappointment.

There were also significant findings when examining the correlations between the emotion socialization variables and company involvement. A positive and significant relationship between company involvement and reasoning to anger and a negative and significant relationship between company involvement and warmth to anger emerged.

In addition, an independent samples t-test was conducted to examine the differences between the childcare as primary and the company group. One significant finding emerged. The fathers who reported higher levels of company involvement $(M=.46, \mathrm{SD}=.37)$ relative to primary childcare involvement $(M=.20, \mathrm{SD}=.24)$ reported significantly higher levels of reasoning in response to their child's anger, $t(32)=-2.49, p=.02$.

\section{Discussion}

The purpose of this study was to examine the relation between the type of paternal involvement and fathers' responses to children's emotions. While change in father's role in childrearing was not examined herein, results support findings from Craig, Smyth, and Powell (2014) suggesting that the father's role is continuing to evolve as more fathers engage more frequently in childcare activities. Specifically, this is evidenced in the finding where fathers reported that they spent half their time with their children engaging in childcare activities and half their time involved in recreational and leisure activities (Craig, Smyth, \& Powell, 2014). When scores were proprotionalized, the primary childcare activities and the time spent in children's company activities composed the two most prominent involvement types. 
When the two father involvement groups were compared, the results provided partial support for the primary hypothesis: that fathers spending most their time in engaging in recreational and leisure activities with their child (company group) would display more supportive responses to their preschool aged children than fathers who spend most their time engaging in childcare activities (childcare primary group). As represented in the independent samples t-test findings, fathers in the child company group reported significantly higher levels of reasoning to anger than the child primary group. However, there was a negative and significant relation between company involvement and warmth responses to anger. While this may seem counterintuitive since reasoning and warmth are both considered supportive strategies, Kennedy Root and Rubin (2010) provide support for the idea that it is likely that one type of supportive strategy might work depending on emotion or context (i.e., reasoning with a child over a disappointing gift seems more appropriate than comforting a child in the same situation).

Although comparisons between the variables were not the primary focus of this study, there were several significant relations that were worth discussing. All directive responses to children's emotions (disappointment, anxiety, and anger) were significantly and positively correlated. Thus, indicating that there is a pattern of how fathers respond to children's negative emotions with directive parenting styles. Fathers consistently responded to children's displays of negative emotions may be considered to have a consistent authoritarian parenting style across children's negative emotional displays. From this data, it appears that fathers do not discriminate to specific negative emotions. This is in contrast to mothers as evidenced by research by Kennedy-Root and Rubin (2010).

When fathers responded to disappointment with intervention strategies, they also responded to anger and anxiety in the same way. While this may seem curious, it makes sense given children can respond to disappointment with blends of sadness and anger. Thus, it seems plausible why fathers would respond in the same fashion. Fathers also responded to disappointment and anxiety with reasoning strategies. Also, fathers responded to disappointment and anger with warmth. Therefore, these findings imply that many fathers may implement the same type of response (reasoning and warmth) to multiple negative emotions.

Fathers that were shown to respond to disappointment with warmth did not respond to disappointment with reasoning. When fathers responded to anxiety using warmth, they did not respond to anxiety using reasoning as a response. Moreover, evidence for distinguishing between 
warmth and reasoning emerged in the examination of their responses to anger and anxiety. When fathers responded to anger with warmth they did not respond to anxiety with reasoning. Fathers that use reasoning as a response to disappointment did not use directive strategies as a response to disappointment. If one is engaging in a non-supportive parenting practice they are less likely to use a supportive parenting practice. Findings with mixed responses such as, fathers' responses to anger using warmth may also use intervention as a response to anger. Thus, this may indicate that some fathers use the same type of responses across a variety of children's emotional displays. Each of these findings show the broad differences in the way fathers respond to their children, which is consistent with the attachment theory. Better put, these findings suggest that during parent-child interactions, parental behavioral systems are activated influencing paternal responses to children in which is based upon the context of the situation (Bowlby, 1969/1982). In addition to Bowlbys theory, Belsky's model also provides logical reasoning to as to the results, some of these findings found within this study may be attributed to fathers' characteristics. All of the participant fathers were heterosexual, most had some type educational background, and the sample was primarily Caucasian therefore, many of these findings may be linked to the lack of diversity within the sample.

\section{Limitations}

Although this study produced some significant results there were many limitations that require attention. This study only examined fathers' involvement with their preschool aged children and their responses to children's displays of emotions. Several child characteristics along with fathers' characteristics were not factored into this study. Blandon (2015) found that fathers responded more negatively to older children's displays of negative emotions. Thus, indicating that age of the child should play a role in fathers responding to their children's emotions. Kennedy-Root and Rubin (2010) found that mothers and fathers often respond differently to girls and boys expressing the same emotion. Because child gender was not examined within the study results may have been hindered.

Not only does children's' characteristics impact father involvement, paternal demographics such as age, income, marital status and relationship quality, co-parenting behaviors, have been shown to play a role in fathers' engagement with their children (Jia and 
Schoppe Sullivan, 2011; Buckley and Schoppe Sullivan, 2010; Belsky, 1984). This is another limitation as it has been stated that fathers' trajectories and demographics influence the role a father plays in a child's life. The sample used within this study was also a limitation. The sample consisted of data collected in 2004-2006 and consisted of only 46 participants; consequently, the sample was restricted to less current data and a small sample does not allow for generalization. Although the sample was drawn from a diverse community (the greater Metropolitan DC area) there was a lack of diversity within the sample in which was restricted to heterosexual fathers of biological children only, fathers were primarily Caucasian, and all participants had some type of higher education experience.

The quality of father engagement measure does not fully capture the father-child relationship dimensions and considering the importance of father child interactions in relation to their responses a more inclusive measure(s) may have bolstered this study. Although fathers were able to independently respond to the emotion stories questionnaire, the coding scheme was created for mother's responses, therefore, this is a limitation. Lastly, by running only correlations and t-tests a full portrayal of the significant relationships (i.e., the direction of the relationship) was not obtained.

\section{Future Directions}

It is first important to reiterate the fact that fathers are relatively understudied and future exploration of fathers' impact on children is a topic that should continue to be explored. The purpose of this study was to gain a better understanding of father's quantity and quality of paternal involvement and its implications for the responses fathers exhibit in times when children display different emotions. It is important for future research to continue to build upon why fathers engage their children as they do, and what factors impact paternal engagement.

As discussed within Belsky's parental determinants model, father's engagement with their child is related to paternal background such as their values, beliefs, perceptions, societal influences, and other relationships. Fathering is a social construct in which there are multiple influences that define what role a father chooses to play in a child's life (Marsiglio \& Cohen, 2000). Therefore, the examination of fathers' history and ideals are important for understanding of what activities and interactions a father chooses to engage in. Fathers metaphilosophies (i.e., beliefs about how emotions should be expressed) also influence how they socialize their 
children's emotions (Marsiglio \& Cohen, 2000). A further examination of more in-depth paternal histories, characteristics, current circumstances, culture, and thought processes is important for a greater understanding of paternal parenting styles especially in relation to emotion socialization strategies.

A more in-depth examination of observed father-child interactions in relation to paternal responding using more inclusive methods of data collection is needed in future studies of this nature. As the emotions stories questionnaire was coded using a coding scheme developed primarily for mothers, a father-based emotion stories coding is needed to bolster accuracy of findings in future studies. Also, a larger and more diverse population should be examined to extend these findings to other cultures. Lastly, fathers' roles are continually evolving (Lamb, 2000) and the fathering construct is a product of culture; therefore, it is continuously evolving and what it means to be a father is changing as cultural perspectives change (Lamb, 2000; Griswold, 1993). Therefore, it is important for future researchers to take this into consideration when examining fathers. 


\section{References}

Ainsworth, M. S. (1989). Attachments beyond infancy. American psychologist, 44(4), 709.

Belsky, J. (1984). The determinants of parenting: A process model. Child development, 83-96.

Blandon, A. Y. (2015). Mothers' and Fathers' Responses to Children's Negative Emotions: Family and Physiological Correlates. Family Relations, 64(3), 431-445.

Bowlby, J. (1969). Attachment and loss v. 3 (Vol. 1). Random House. Furman, W., \& Buhrmester, D. (2009). Methods and measures: The network of relationships inventory: Behavioral systems version. International Journal of Behavioral Development, 33, 470478.

Bowlby, J. (1982). Attachment and loss: Attachment (Vol. 1, 2nd ed.). New York: Basic Books.

Brown, G. L., Mangelsdorf, S. C., \& Neff, C. (2012). Father involvement, paternal sensitivity, and father- child attachment security in the first 3 years. Journal of Family Psychology, 26(3), 421.

Buckley, C. K., \& Schoppe-Sullivan, S. J. (2010). Father involvement and coparenting behavior: Parents' nontraditional beliefs and family earner status as moderators. Personal Relationships, 17(3), 413-431.

Craig, L., Powell, A., \& Smyth, C. (2014). Towards intensive parenting? Changes in the composition and determinants of mothers' and fathers' time with children 1992-2006. The British journal of sociology, 65(3), 555-579.

Denham, S. A., Bassett, H. H., \& Wyatt, T. (2015). The socialization of emotional competence. Handbook of socialization: Theory and research, 614-637. 
Denham, S. A., Bassett, H. H., \& Wyatt, T. M. (2010). Gender differences in the socialization of preschoolers' emotional competence. New Directions for child and adolescent development, 2010(128), 29-49.

Denham, S. A., \& Grout, L. (1992). Mothers' emotional expressiveness and coping: Relations with preschoolers' social-emotional competence. Genetic, Social, and General Psychology Monographs, 118, 75-101.

Denham, S., \& Kochanoff, A. T. (2002). Parental contributions to preschoolers' understanding of emotion. Marriage \& Family Review, 34(3-4), 311-343.

Denham, S. A., Mitchell-Copeland, J., Strandberg, K., Auerbach, S., \& Blair, K. (1997). Parental contributions to preschoolers' emotional competence: Direct and indirect effects. Motivation and emotion, 21(1), 65-86.

Easterbrooks, M. A., \& Goldberg, W. A. (1984). Toddler development in the family: Impact of father involvement and parenting characteristics. Child development, 740-752.

Eisenberg, N., Cumberland, A., \& Spinrad, T. L. (1998). Parental socialization of emotion. Psychological inquiry, 9(4), 241-273.

Fabes, R. A., Poulin, R. E., Eisenberg, N., \& Madden-Derdich, D. A. (2002). The Coping with Children's Negative Emotions Scale (CCNES): Psychometric properties and relations with children's emotional competence. Marriage \& Family Review, 34, 285-310.

Gottman, J. M., Katz, L. F., \& Hooven, C. (1997). Meta-emotion: How families communicate emotionally. Psychology Press. 
Grossmann, K. E., \& Volkmer, H. J. (1984). Fathers' presence during birth of their infants and paternal involvement. International Journal of Behavioral Development, 7(2), 157-165.

Jia, R., \& Schoppe-Sullivan, S. J. (2011). Relations between co-parenting and father involvement in families with preschool-age children. Developmental Psychology, 47(1), 106-118.

Kennedy Root, A., \& Rubin, K. H. (2010). Gender and parents' reactions to children's emotions during preschool years. In A. Kennedy Root \& S. Denham (Eds.), The role of gender in the socialization of emotion: Key concepts and critical issues. New Directions for Child and Adolescent Development, 128, 51-64. San Francisco: Jossey-Bass.

Kerns, K. A. (2008). Attachment in middle childhood. Guilford Press.

Lamb, M. E. (2000). The history of research on father involvement: An overview. Marriage \& Family Review, 29, 23-42.

Lamb, M. E., Pleck, J. H., Charnov, E. L., \& Levine, J. A. (1985). Paternal behavior in humans. American Zoologist, 25, 883-894.

Griswold, R. L. (1993). Fatherhood in America: A history. New York: Basic Books.

Marsiglio, W., \& Cohen, M. (2000). Conceptualizing father involvement and paternal influence: Sociological and qualitative themes. Marriage and Family Review, 29, 75-95.

Morman, M. T., \& Floyd, K. (2006). Good fathering: Father and son perceptions of what it means to be a good father. Fathering, 4(2), 113. 
Olmstead, S. B., Futris, T. G., \& Pasley, K. (2009). An exploration of married and divorced, nonresident men's perceptions and organization of their father role identity. Fathering, 7(3), 249.

Pleck, J. H. (2012). Integrating father involvement in parenting research. Parenting, 12(2-3), 243-253.

Spinrad, T. L., Stifter, C. A., Donelan-McCall, N., \& Turner, L. (2004). Mothers' Regulation Strategies in Response to Toddlers' Affect: Links to Later Emotion SelfRegulation. Social Development, 13(1), 40-55. 
Table 1

Descriptive Statistics for all Variables of Interest

\begin{tabular}{|c|c|c|c|c|}
\hline $\begin{array}{l}\text { Variable of } \\
\text { Interest }\end{array}$ & Mean & $\begin{array}{l}\text { Standard } \\
\text { Deviation }\end{array}$ & Minimum & Maximum \\
\hline Primary & $18.065(47 \%)$ & 8.0950 & .0 & 34.5 \\
\hline Secondary & $1.935(5 \%)$ & 3.0616 & .0 & 10.0 \\
\hline Company & $17.457(46 \%)$ & 8.2710 & .0 & 41.0 \\
\hline Mixed & $.902(2 \%)$ & 3.9010 & .0 & 23.5 \\
\hline Uncodable & $12.511(3 \%)$ & 20.3943 & .0 & 73.5 \\
\hline Total & 38.489 & 10.7597 & 20.0 & 59.0 \\
\hline Direct - Anger & .3473 & .33567 & .00 & 1.00 \\
\hline Direct - Anxious & .0090 & .05480 & .00 & .33 \\
\hline $\begin{array}{l}\text { Direct - } \\
\text { Disappointment }\end{array}$ & .0912 & .21805 & .00 & 1.00 \\
\hline $\begin{array}{l}\text { Intervention - } \\
\text { Anger }\end{array}$ & .1784 & .20775 & .00 & .50 \\
\hline $\begin{array}{l}\text { Intervention - } \\
\text { Anxious }\end{array}$ & .1811 & .18271 & .00 & .50 \\
\hline $\begin{array}{l}\text { Intervention - } \\
\text { Disappointment }\end{array}$ & .1051 & .16397 & .00 & .67 \\
\hline $\begin{array}{l}\text { Reasoning - } \\
\text { Anger }\end{array}$ & .3473 & .34110 & .00 & 1.00 \\
\hline
\end{tabular}




$\begin{array}{lccccc}\text { Reasoning - Fear } & .2892 & .27220 & .00 & 1.00 & 37 \\ \begin{array}{l}\text { Reasoning - } \\ \text { Disappointment }\end{array} & .3120 & .29557 & .00 & 1.00 & 36 \\ \begin{array}{l}\text { Warmth - Anger } \\ \text { Warmth - }\end{array} & .0730 & .17753 & .00 & .67 & 37 \\ \begin{array}{l}\text { Anxious } \\ \text { Warmth - }\end{array} & .3134 & .30120 & .00 & 1.00 & 37 \\ \text { Disappointment } & & .21525 & .00 & .67 & 36\end{array}$


Table 2

Correlations between Fathers Involvement Codes

1.

1. Primary

2. Secondary

3. Company

4. Mixed

5. Total
$-$

.17

$-.27^{\mathrm{t}}$

$-.03$

$.59 * *$
2.

$-.21$

$-.10$

.21
3.

$-.09$

$.49 * *$
4.

.24 
Table 3

Correlations between Total Involvement, Primary Involvement, and Company Involvement

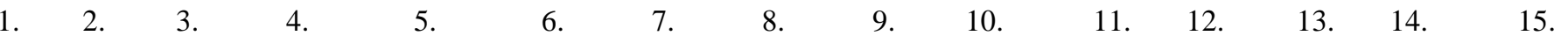

1. Total

$$
--
$$

2. Primary

.59

3. Company

$.50 \quad-265$

4. Direct - Anxious

$\begin{array}{llll}.20 & .094 & -.091 & --\end{array}$

5. Direct - Anger

$\begin{array}{lllll}.110 & .257 & -.178 \quad .329 * \quad--\end{array}$

6. Direct -

$\begin{array}{llllll}.106 & .125 & -.217 & .714 * * & .424 * & --\end{array}$

Disappointment

7. Intervention$\begin{array}{llllllll} & 188 & .130 & .106 & .141 & -.074 & -.089 & --\end{array}$

Anxious

8. InterventionAnger

$\begin{array}{llllll}.044 & .091 & -.031 & -.145 & -.144 & .135\end{array}$

Intervention Disappointment

$$
\text { - }
$$

10. Reasoning Anxious

$.079 \quad .226$

1. ReasoningAnger

$\begin{array}{ll}- & - \\ .021 & .030 \\ .094 & -5\end{array}$

$.094-$
-318

12. Reasoning Disappointment

$\begin{array}{llll}- & .077 & -.001 & -.181\end{array}$

Warmth -

Anxious

$\begin{array}{lllll}- & .019 & -.090 & -.082 & .248 \\ .033 & & & & \end{array}$

$\begin{array}{llll}- & -.113 & .074 & - \\ .419 * & & & .125\end{array}$

$.000 \quad-.275$

$\begin{array}{lllll}.000 & -.067 & - & -.682 * * & - \\ & & .114 & & .246\end{array}$


14. Warmth - Anger

$\begin{array}{lll}.164 & - & -.069\end{array}$

$-.247$

$-.180$

$.343^{*}$

$-.312$

.013

$-.348 *$

$-135$

$-.123$

$.176 \quad--$

15. Warmth -

Disappointment

.068

$\begin{array}{lll}.144 & -.278 & -.250\end{array}$

$-.228$

$-.107 \quad .216$

$\begin{array}{lll}.184 & .169 & -.152\end{array}$

.106

. $366^{*}$

$.092 .456 *$ 


\section{APPENDIX A}

Demographic Information

\section{Child's Name}

Birthdate Age Boy Girl

Month Day Year

Child's Country of Birth

Is your child biological? Adopted? Foster child?

Age adopted

Age when fostering began

Name of preschool:

PART A:

Child's mother's name (biological/natural) First Last

Age

Occupation

Mother's education completed: $\quad$ Elementary School

High School

Vocational School

Some College

University Degree

Some Graduate School

Graduate Degree

Other(specify)

Mother's country of birth

Mother's ethnic background:

White

Latino/Hispanic

Black

Asian

Native American

Other (specify) 
Mother's Marital Status with child's biological father:
Married

Separated

Divorced

Common law

Single

Other (specify)

Mother's current relationship status (check one): Married

Separated

Divorced

Common law

Single

Living with partner

Other (specify)

PART B:

Child's father's name (biological)

Age

First

Last

Occupation

Father's education completed: $\quad$ Elementary School

High School

Vocational School

Some College

University Degree

Some Graduate School

Graduate Degree

Other (specify)

Father's country of birth

Father's ethnic background:

White

Latino/Hispanic

Black

Asian

Native American

Other (specify)

Father's Marital Status with

Married

child's biological mother:

Separated

Divorced

Common law

Single

Other (specify) 
If either the child's biological mother or biological father has been married previously, please indicate the following:

$\begin{array}{lll}\text { Previous marriage(s): } & \text { Mother }(\mathrm{Yes} / \mathrm{No}) & \text { Length of marriage(yrs.) } \\ & \text { Father }(\mathrm{Yes} / \mathrm{No}) & \text { Length of marriage(yrs.) }\end{array}$

Other children -- Please list all children of either partner, whether or not they are living at home:

What are the What are the biological names of the parents' names of other children? the other children? Birthdate?
What was the last grade of school completed?
Are they living at at home or away?

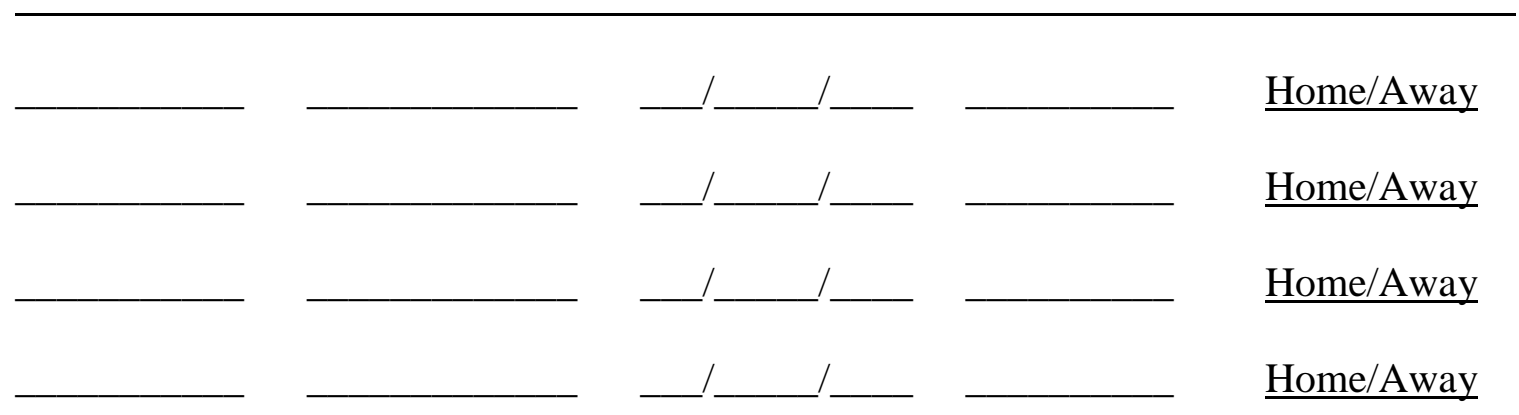

Other adults living with the family:

(e.g., grandparents, mother's partner, aunt/uncle)

Name:

Relationship to child:

Length of time living with family:

Name:

Relationship to child:

Length of time living with family:

PART C - If the child has a stepmother, please complete Part C also, if applicable:

First Last


Age

Occupation

Stepmother's education completed: Elementary School

High School

Vocational School

Some College

University Degree

Some Graduate School

Graduate Degree

Other (specify)

Stepmother's country of birth

Stepmother's ethnic background: White

Latino/Hispanic

Black

Asian

Native American

Other (specify)

Stepmother's Current

Marital Status (check one): Married

Separated

Divorced

Common law

Single

Other (specify)

PART D - If the child has a stepfather, please complete Part D also, if applicable:

Child's stepfather's name

Age

First Last

Occupation

Stepfather's education completed: Elementary School

High School

Vocational School 


Some College
University Degree
Some Graduate School
Graduate Degree
Other (specify)

Stepfather's country of birth

Stepfather's ethnic background: White

Latino/Hispanic

Black

Asian

Native American

Other (specify)

Stepfather's Current

Marital Status (check one): Married

Separated

Divorced

Common law

Single

Other (specify) 
PART E: Please indicate the time spent with your child and activities you engage in with your child on a weekly basis in the schedule below.

\begin{tabular}{|c|c|c|c|c|c|c|c|}
\hline & Monday & Tuesday & Wednesday & Thursday & Friday & Saturday & Sunday \\
\hline $6: 00$ & & & & & & & \\
\hline $7: 00$ & & & & & & & \\
\hline $8: 00$ & & & & & & & \\
\hline 9:00 & & & & & & & \\
\hline $10: 00$ & & & & & & & \\
\hline $11: 00$ & & & & & & & \\
\hline $12: 00$ & & & & & & & \\
\hline $1: 00$ & & & & & & & \\
\hline $2: 00$ & & & & & & & \\
\hline $3: 00$ & & & & & & & \\
\hline $4: 00$ & & & & & & & \\
\hline 5:00 & & & & & & & \\
\hline $6: 00$ & & & & & & & \\
\hline 7:00 & & & & & & & \\
\hline $8: 00$ & & & & & & & \\
\hline 9:00 & & & & & & & \\
\hline $10: 00$ & & & & & & & \\
\hline
\end{tabular}




\section{Appendix B}

INVOLVEMENT CODING

ID \#

MOTHER REPORT

FATHER REPORT

(circle one)

CODER INITIALS

98 HOURS INDICATED ON CODING SHEET (ROUND TO CLOSEST 1/2 HOUR)

\section{CHILDCARE AS PRIMARY ACTIVITY}

- INTERACTIVE TALK-BASED ACTIVITY (talking, teaching, homework, learning)

- PHYSICAL CARE (feeding, bathing, dressing, getting ready, putting child to bed (bedtime/bed), morning routine, etc.)

- ACCOMPANYING CARE (transporting, traveling, waiting for or meeting children, ensuring safety or handing over to another care-giver)

TOTAL NUMBER OF HOURS INDICATED:

\section{CHILDCARE AS A SECONDARY ACTIVITY}

- SUPERVISING CHILDREN WITHOUT ENGAGEMENT (cooking dinner while watching over child, sports practice, chores, playdates, etc.)

TOTAL NUMBER OF HOURS INDICATED:

\section{TIME SPENT IN CHILRENS COMPANY}

- RECREATION \& LEISURE ACTIVITIES (sports, outdoor activities, games, hobbies, reading, watching TV, playing, etc.)

- SOCIAL \& COMMUNITY INTERACTION (socializing, attending a movie, shopping, concerts, museums, religious activities, out to eat, etc.)

TOTAL NUMBER OF HOURS INDICATED:

MIXED RESPONSES THAT CANNOT BE SEPERATED: Code in this category if time cannot be separated into $1 / 2$ hours but all the reported activities within the time block can be categorized. 
TOTAL NUMBER OF HOURS INDICATED:

UNCODABLE (Code in this category if responses are not clear, activity is not related to parent/child time spent or if activity is not related to any other category)

**Please indicate reason for uncodable hours:

TOTAL NUMBER OF HOURS SPENT WITH CHILD PER WEEK: 


\section{Appendix C}

\section{CHILDREN'S EMOTIONS STORIES}

In this section, there are eight brief stories. Each story depicts a parent and a child, sometimes by themselves and sometimes with other adults or children. As you read each story, please imagine that you and your child, the one you have given permission to take part in this study, are the characters described in the situation.

Following each story, there are five questions. Please read each question carefully. First, you are asked how you would feel seeing your child behaving in a certain manner. Second, you are asked what, if anything, you would do to handle the situation depicted in the story, and whether or not you would be trying to teach your child some rule by dealing with things that way. Then, a specific rule is described, and you are asked to make three ratings of that rule on five point scales. Please rate how regularly you enforce that rule, how often you need to remind your child of that rule, and how well your child follows that rule when you do remind him or her.

Some of the stories may depict situations that you have never experienced with your child. However, we are still interested in how you think you would deal with these situations, if they did come up. Therefore, please read all eight of the stories and answer each of the questions that follows. 


\section{STORIES}

Story 1:

It is your sister's birthday and she has invited the whole family to celebrate by going out for dinner. The restaurant she has chosen is rather elegant and formal. During the dinner, your child exuberantly jumps out of his/her chair and shouts, "Happy birthday, Auntie!"

(1) How would you feel when you see your child display their happiness in front of others?

How angry?

How disgusted?

How embarrassed?

How anxious?

How surprised?

How happy?

How sad?
1
Not at all

1

Not at all

1

Not at all

1

Not at all

1
Not at all

1

Not at all

1
Not at all

2
a bit

3
quite a bit

\section{2}

a bit

\section{2}

a bit

\section{2}

a bit

\section{2}

a bit

\section{2}

a bit

2

a bit

\section{3 \\ quite a bit}

3

quite a bit

\section{3}

quite a bit

3

quite a bit

\section{3}

quite a bit

3

quite a bit

4
a lot

4

a lot

4

a lot

4

a lot

4

a lot

4

a lot

4

a lot
5

extremely

5

extremely

5

extremely

5

extremely

5

extremely

5

extremely

5

extremely

(2) (a) What, if anything, might you do in response to your child displaying happiness in front of others? 
Story 2

One afternoon, your child comes in after playing with friends. He/She was teased and called names by another youngster, and she/he arrives home trembling and tearful.

(1) How would you feel when you see your child display their anxiety just in front of you?

\begin{tabular}{|c|c|c|c|c|c|}
\hline How angry? & $\begin{array}{c}1 \\
\text { Not at all }\end{array}$ & $\begin{array}{l}2 \\
\text { a bit }\end{array}$ & $\begin{array}{c}3 \\
\text { quite a bit }\end{array}$ & $\begin{array}{l}4 \\
\text { a lot }\end{array}$ & $\begin{array}{c}5 \\
\text { extremely }\end{array}$ \\
\hline How disgusted? & $\begin{array}{c}1 \\
\text { Not at all }\end{array}$ & $\begin{array}{l}2 \\
\text { a bit }\end{array}$ & $\begin{array}{c}3 \\
\text { quite a bit }\end{array}$ & $\begin{array}{l}4 \\
\text { a lot }\end{array}$ & $\begin{array}{c}5 \\
\text { extremely }\end{array}$ \\
\hline How embarrassed? & $\begin{array}{c}1 \\
\text { Not at all }\end{array}$ & $\begin{array}{l}2 \\
\text { a bit }\end{array}$ & $\begin{array}{c}3 \\
\text { quite a bit }\end{array}$ & $\begin{array}{l}4 \\
\text { a lot }\end{array}$ & $\begin{array}{c}5 \\
\text { extremely }\end{array}$ \\
\hline How anxious? & $\begin{array}{c}1 \\
\text { Not at all }\end{array}$ & $\begin{array}{l}2 \\
\text { a bit }\end{array}$ & $\begin{array}{c}3 \\
\text { quite a bit }\end{array}$ & $\begin{array}{l}4 \\
\text { a lot }\end{array}$ & $\begin{array}{c}5 \\
\text { extremely }\end{array}$ \\
\hline How surprised? & $\begin{array}{c}1 \\
\text { Not at all }\end{array}$ & $\begin{array}{l}2 \\
\text { a bit }\end{array}$ & $\begin{array}{c}3 \\
\text { quite a bit }\end{array}$ & $\begin{array}{l}4 \\
\text { a lot }\end{array}$ & $\begin{array}{c}5 \\
\text { extremely }\end{array}$ \\
\hline How happy? & $\begin{array}{c}1 \\
\text { Not at all }\end{array}$ & $\begin{array}{l}2 \\
\text { a bit }\end{array}$ & $\begin{array}{c}3 \\
\text { quite a bit }\end{array}$ & $\begin{array}{l}4 \\
\text { a lot }\end{array}$ & $\begin{array}{c}5 \\
\text { extremely }\end{array}$ \\
\hline How sad? & $\begin{array}{c}1 \\
\text { Not at all }\end{array}$ & $\begin{array}{l}2 \\
\text { a bit }\end{array}$ & $\begin{array}{c}3 \\
\text { quite a bit }\end{array}$ & $\begin{array}{l}4 \\
\text { a lot }\end{array}$ & $\begin{array}{c}5 \\
\text { extremely }\end{array}$ \\
\hline
\end{tabular}

(2) (a) What, if anything, might you do in response to your child displaying anxiety just in front of you? 
Story 3

It is 15 minutes until dinner is ready. Your child asks for a cookie because she/he is "starving". You explain that dinner will be ready in 15 minutes and that she/he will have to wait until then. Your child yells and stomps his or her feet continuously.

(1) How would you feel when you see your child display their anger just in front of you?

How angry?

How disgusted?

How embarrassed?

How anxious?

How surprised?

How happy?

How sad?
1
Not at all

$$
1
$$$$
\text { Not at all }
$$

1
Not at al

Not at all

1
Not at all

1
Not at a

Not at all

1
Not at all

1

Not at all
2

a bit

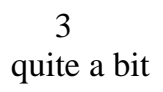

2

a bit

3
quite a bit

2

a bit

3

quite a bit

2

a bit

3

quite a bit

2

a bit

3

quite a bit

\section{2}

a bit

3

quite a bit

2

a bit
4

a lot

4

a lot

4

a lot

4

a lot

4

a lot

4

a lot

4

a lot
5

extremely

5

extremely

5

extremely

5

extremely

5

extremely

5

extremely

5

extremely

(2) (a) What, if anything, might you do in response to your child displaying anger just in front of you? 
Story 4

On a visit to the fair, your child enters a contest and wins a stuffed dog. This is the first contest your child has ever won, so the toy becomes a prized possession. Before too long, however, your child loses the dog while out playing and comes running to you in tears.

(1) How would you feel when you see your child display their disappointment just in front of you?

\begin{tabular}{|c|c|c|c|c|c|}
\hline How angry? & $\begin{array}{c}1 \\
\text { Not at all }\end{array}$ & $\begin{array}{l}2 \\
\text { a bit }\end{array}$ & $\begin{array}{c}3 \\
\text { quite a bit }\end{array}$ & $\begin{array}{l}4 \\
\text { a lot }\end{array}$ & $\begin{array}{c}5 \\
\text { extremely }\end{array}$ \\
\hline How disgusted? & $\begin{array}{c}1 \\
\text { Not at all }\end{array}$ & $\begin{array}{l}2 \\
\text { a bit }\end{array}$ & $\begin{array}{c}3 \\
\text { quite a bit }\end{array}$ & $\begin{array}{l}4 \\
\text { a lot }\end{array}$ & $\begin{array}{c}5 \\
\text { extremely }\end{array}$ \\
\hline How embarrassed? & $\begin{array}{c}1 \\
\text { Not at all }\end{array}$ & $\begin{array}{l}2 \\
\text { a bit }\end{array}$ & $\begin{array}{c}3 \\
\text { quite a bit }\end{array}$ & $\begin{array}{l}4 \\
\text { a lot }\end{array}$ & $\begin{array}{c}5 \\
\text { extremely }\end{array}$ \\
\hline How anxious? & $\begin{array}{c}1 \\
\text { Not at all }\end{array}$ & $\begin{array}{l}2 \\
\text { a bit }\end{array}$ & $\begin{array}{c}3 \\
\text { quite a bit }\end{array}$ & $\begin{array}{l}4 \\
\text { a lot }\end{array}$ & $\begin{array}{c}5 \\
\text { extremely }\end{array}$ \\
\hline How surprised? & $\begin{array}{c}1 \\
\text { Not at all }\end{array}$ & $\begin{array}{l}2 \\
\text { a bit }\end{array}$ & $\begin{array}{c}3 \\
\text { quite a bit }\end{array}$ & $\begin{array}{l}4 \\
\text { a lot }\end{array}$ & $\begin{array}{c}5 \\
\text { extremely }\end{array}$ \\
\hline How happy? & $\begin{array}{c}1 \\
\text { Not at all }\end{array}$ & $\begin{array}{l}2 \\
\text { a bit }\end{array}$ & $\begin{array}{c}3 \\
\text { quite a bit }\end{array}$ & $\begin{array}{l}4 \\
\text { a lot }\end{array}$ & $\begin{array}{c}5 \\
\text { extremely }\end{array}$ \\
\hline How sad? & $\begin{array}{c}1 \\
\text { Not at all }\end{array}$ & $\begin{array}{l}2 \\
\text { a bit }\end{array}$ & $\begin{array}{c}3 \\
\text { quite a bit }\end{array}$ & $\begin{array}{l}4 \\
\text { a lot }\end{array}$ & $\begin{array}{c}5 \\
\text { extremely }\end{array}$ \\
\hline
\end{tabular}

(2) (a) What, if anything, might you do in response to your child displaying disappointment just in front of you ? 
Story 5

You're having a birthday party for your child, and you have everyone gather around while your child opens her/his gifts. Your child is obviously very disappointed about one of the gifts, and it shows all over her/his face and in her/his voice.

(1) How would you feel when you see your child display their disappointment in front of others?

How angry?

How disgusted?

How embarrassed?

How anxious?

How surprised?

How happy?

How sad?
1
Not at all

1

Not at all

1
Not at al

Not at all

1
Not at all

1
Not at all

1

Not at all

1

Not at all
2

a bit

quite a bit

2

a bit

3
quite a bit

2

a bit

3

quite a bit

2

a bit

3

quite a bit

2

a bit

3

quite a bit

2

a bit

3

quite a bit

2

a bit
4

a lot

4

a lot

4

a lot

4

a lot

4

a lot

4

a lot

4

a lot
5

extremely

5

extremely

5

extremely

5

extremely

5

extremely

5

extremely

5

extremely

(2) (a) What, if anything, might you do in response to your child displaying disappointment in front of others? 
Story 6

You and your child are in a toy store. Your child asks you to buy him/her a new toy. You tell your child no, that she/he just received several new toys at her/his birthday party, and then you go to leave the store. Your child throws her/himself onto the floor kicking and screaming, yelling that she/he wants the toy. Your child will not leave the store.

(1) How would you feel when you see your child display their anger in front of others?

\begin{tabular}{|c|c|c|c|c|c|}
\hline How angry? & $\begin{array}{c}1 \\
\text { Not at all }\end{array}$ & $\begin{array}{l}2 \\
\text { a bit }\end{array}$ & $\begin{array}{c}3 \\
\text { quite a bit }\end{array}$ & $\begin{array}{l}4 \\
\text { a lot }\end{array}$ & $\begin{array}{c}5 \\
\text { extremely }\end{array}$ \\
\hline How disgusted? & $\begin{array}{c}1 \\
\text { Not at all }\end{array}$ & $\begin{array}{l}2 \\
\text { a bit }\end{array}$ & $\begin{array}{c}3 \\
\text { quite a bit }\end{array}$ & $\begin{array}{l}4 \\
\text { a lot }\end{array}$ & $\begin{array}{c}5 \\
\text { extremely }\end{array}$ \\
\hline How embarrassed? & $\begin{array}{c}1 \\
\text { Not at all }\end{array}$ & $\begin{array}{l}2 \\
\text { a bit }\end{array}$ & $\begin{array}{c}3 \\
\text { quite a bit }\end{array}$ & $\begin{array}{l}4 \\
\text { a lot }\end{array}$ & $\begin{array}{c}5 \\
\text { extremely }\end{array}$ \\
\hline How anxious? & $\begin{array}{c}1 \\
\text { Not at all }\end{array}$ & $\begin{array}{l}2 \\
\text { a bit }\end{array}$ & $\begin{array}{c}3 \\
\text { quite a bit }\end{array}$ & $\begin{array}{l}4 \\
\text { a lot }\end{array}$ & $\begin{array}{c}5 \\
\text { extremely }\end{array}$ \\
\hline How surprised? & $\begin{array}{c}1 \\
\text { Not at all }\end{array}$ & $\begin{array}{l}2 \\
\text { a bit }\end{array}$ & $\begin{array}{c}3 \\
\text { quite a bit }\end{array}$ & $\begin{array}{c}4 \\
\text { a lot }\end{array}$ & $\begin{array}{c}5 \\
\text { extremely }\end{array}$ \\
\hline How happy? & $\begin{array}{c}1 \\
\text { Not at all }\end{array}$ & $\begin{array}{l}2 \\
\text { a bit }\end{array}$ & $\begin{array}{c}3 \\
\text { quite a bit }\end{array}$ & $\begin{array}{l}4 \\
\text { a lot }\end{array}$ & $\begin{array}{c}5 \\
\text { extremely }\end{array}$ \\
\hline How sad? & $\begin{array}{c}1 \\
\text { Not at all }\end{array}$ & $\begin{array}{l}2 \\
\text { a bit }\end{array}$ & $\begin{array}{c}3 \\
\text { quite a bit }\end{array}$ & $\begin{array}{c}4 \\
\text { a lot }\end{array}$ & $\begin{array}{c}5 \\
\text { extremely }\end{array}$ \\
\hline
\end{tabular}

(2) (a) What, if anything, might you do in response to your child displaying anger in front of others? 
Story 7

You've moved into a new neighborhood, and your child is invited to a birthday party being held for the child next door. You take your child to the party and stay awhile. You notice that your child looks very nervous and uncomfortable, and is keeping to her/himself.

(1) How would you feel when you see your child display their anxiety in front of others?

\begin{tabular}{|c|c|c|c|c|c|}
\hline How angry? & $\begin{array}{c}1 \\
\text { Not at all }\end{array}$ & $\begin{array}{l}2 \\
\text { a bit }\end{array}$ & $\begin{array}{c}3 \\
\text { quite a bit }\end{array}$ & $\begin{array}{l}4 \\
\text { a lot }\end{array}$ & $\begin{array}{c}5 \\
\text { extremely }\end{array}$ \\
\hline How disgusted? & $\begin{array}{c}1 \\
\text { Not at all }\end{array}$ & $\begin{array}{l}2 \\
\text { a bit }\end{array}$ & $\begin{array}{c}3 \\
\text { quite a bit }\end{array}$ & $\begin{array}{l}4 \\
\text { a lot }\end{array}$ & $\begin{array}{c}5 \\
\text { extremely }\end{array}$ \\
\hline How embarrassed? & $\begin{array}{c}1 \\
\text { Not at all }\end{array}$ & $\begin{array}{l}2 \\
\text { a bit }\end{array}$ & $\begin{array}{c}3 \\
\text { quite a bit }\end{array}$ & $\begin{array}{l}4 \\
\text { a lot }\end{array}$ & $\begin{array}{c}5 \\
\text { extremely }\end{array}$ \\
\hline How anxious? & $\begin{array}{c}1 \\
\text { Not at all }\end{array}$ & $\begin{array}{l}2 \\
\text { a bit }\end{array}$ & $\begin{array}{c}3 \\
\text { quite a bit }\end{array}$ & $\begin{array}{l}4 \\
\text { a lot }\end{array}$ & $\begin{array}{c}5 \\
\text { extremely }\end{array}$ \\
\hline How surprised? & $\begin{array}{c}1 \\
\text { Not at all }\end{array}$ & $\begin{array}{l}2 \\
\text { a bit }\end{array}$ & $\begin{array}{c}3 \\
\text { quite a bit }\end{array}$ & $\begin{array}{l}4 \\
\text { a lot }\end{array}$ & $\begin{array}{c}5 \\
\text { extremely }\end{array}$ \\
\hline How happy? & $\begin{array}{c}1 \\
\text { Not at all }\end{array}$ & $\begin{array}{l}2 \\
\text { a bit }\end{array}$ & $\begin{array}{c}3 \\
\text { quite a bit }\end{array}$ & $\begin{array}{l}4 \\
\text { a lot }\end{array}$ & $\begin{array}{c}5 \\
\text { extremely }\end{array}$ \\
\hline How sad? & $\begin{array}{c}1 \\
\text { Not at all }\end{array}$ & $\begin{array}{l}2 \\
\text { a bit }\end{array}$ & $\begin{array}{c}3 \\
\text { quite a bit }\end{array}$ & $\begin{array}{l}4 \\
\text { a lot }\end{array}$ & $\begin{array}{c}5 \\
\text { extremely }\end{array}$ \\
\hline
\end{tabular}

(2) (a) What, if anything, might you do in response to your child displaying anxiety in front of others? 
Story 8

Your child has a race with friends in the neighborhood, comes in first, and is very excited. When you get home, for a long time, your child continues to jump around gleefully and exclaim to you about her/his victory.

1) How would you feel when you see your child display their happiness just in front of you?

How angry?

How disgusted?

How embarrassed?

How anxious?

How surprised?

How happy?

How sad?

\section{Not at all}

$$
1
$$

Not at all

1
Not at all

1
Not at all

1

Not at all

1

Not at all

1

2

a bit

2

a bit

2

a bit

2

a bit

\section{2}

a bit

2

a bit

2

a bit

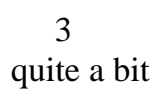

3

quite a bit

\section{3}

quite a bit

3

quite a bit

\section{3}

quite a bit

3

quite a bit

\section{3}

quite a bit
4

a lot

4

a lot

4

a lot

4

a lot

4

a lot

4

a lot

4

a lot
5

extremely

5

extremely

5

extremely

5

extremely

5

extremely

5

extremely

5

extremely

(2) (a) What, if anything, might you do in response to your child displaying happiness just in front of you? 


\section{Appendix D \\ Emotion Story Coding}

Does Nothing (DN): Parent ignores or does nothing in response to child's behavior or emotional expression.

Direct Command- Behavior (DC-B): With reference to child's behavior, parent makes a verbal command intended to obtain child's compliance with rules, norms, or expectations. The command is given using imperative speech forms (e.g., "In this building you have to talk quietly").

Direct Command- Feelings (DC-F): With reference to child's expression of emotion, parent makes a verbal command intended to obtain child's compliance with rules, norms, or expectations. The command is given using imperative speech forms (e.g., "Stop crying now"). Indirect Command- Behavior (IC-B): With reference to child's behavior, parent makes a verbal command related to child's compliance with rules, norms, or expectations, however, the command is given using a polite speech form (deferential, interrogative, or passive forms) (e.g., "ask her to return to her seat").

Indirect Command- Feelings (IC-F): With reference to child's expression of emotion, parent makes a verbal command related to child's compliance with rules, norms, or expectations, however, the command is given using a polite speech form (deferential, interrogative, or passive forms) (e.g., "Try to stop your crying now, okay?").

Punishment (PUN): Parent imposes a negative consequence (or threatens to do so) on child's behavior (e.g., "If you need to yell and stomp go to your room").

Criticize Behavior (C-B): Parent negatively evaluates her child's behavior (including child's expression of emotion) (e.g., "That's not a nice way to act when someone gives you a gift"). 
Criticize Child (C-C): Parent negatively evaluates child's character or personality (e.g., "You are a bad girl").

Guidance/ Pragmatic Solutions (GP): Parent attempts to re-focus or divert child's attention; suggests alternate activities (e.g., "comment positively on wrapping, bow, card"; "offer something nutritious to eat"; "try to focus on something positive about the gift").

Support/ Acknowledge- Behaviors (SA-B): Parent encourages, supports, reassures or shows appreciation for child. Includes acknowledging child's expressed thoughts or actions and initiating discussion with child about child's behaviors.

Support/ Acknowledge Feelings (SA-F): Parent encourages, supports, reassures or shows appreciation for child's expressed feelings or emotions. Includes initiating discussion with child about child's feelings (e.g., "I know you are very excited"; "talk to him about how it feels to be teased"; "It is sad to lose something special").

Affection/ Comfort (AC): Parent expresses affection either physically (e.g., hug, kiss) or verbally (e.g., "comfort her and tell her I love her). Contact may be spontaneous or in response to child's distress or happiness.

Question- Situation (Q-S): Parent asks a question in order to better understand the situation (e.g., "Tell me what happened"; "How did you lose the toy?").

Question- Feelings (Q-F): Parent asks a question in order to better understand child's feelings (e.g., "Tell me why you are so upset"; "How does it make you feel to win").

Praise Behavior (P-B): Parent positively evaluates child's behavior (including emotional expression) (e.g., "It was nice of you to say Happy Birthday to your aunt"; "praise her for running fast"). 
Praise Child (P-C): Parent positively evaluates child's character or personality (e.g., "tell her she is a good person").

Model (MOD): Parent demonstrates appropriate behavior to child, with the possibility of teaching or training child (e.g., "make an excited facial expression when I realize my son isn't happy over the gift").

Reasoning (REA): Parent explains why child should behave a certain way, or points out the natural consequences of child's behavior. Includes moral reasoning. (e.g., "It's the thought that counts"; "remind him that it was his responsibility to keep track of it").

Other-Oriented Reasoning (OOR): Parent explains why the child's behavior is right or wrong by pointing out the consequences of their behavior for another person or makes child aware of another's point of view, state of mind and/or emotions (e.g., "Noisy voices in this restaurant make people feel angry"; "remind him that the other children tried their best as well").

Indirect Intervention (II): Parent joins child in trying to solve problem or work through the situation (e.g., "attempt to make him more comfortable by playing with him and the other kids"). Child has option to participate with parent (e.g., ask her after a while if she would like to leave or go home").

Direct Intervention (DI): Parent intervenes without involving child in process (e.g., "contact other parent and discuss incident"); or without giving child option to take part (e.g., "pick her up and carry her out"). 
$\underline{\text { Factor analysis for paternal emotion socialization strategies }}$

Code

Factor 1

Factor 2

Directiveness

Direct Command Behav. $\quad .74$

Punishment $\quad .74$

Eigenvalue $\quad 1.09$

Intervention

Direct Intervention $\quad .82$

Indirect Intervention $\quad .82$

Guidance/Pragmatic Solutions $\quad .14$

$\begin{array}{ll}\text { Eigenvalue } & 1.37\end{array}$

Reasoning

Indirect Command Behav. $\quad-.53 \quad-.08$

Question Situation $\quad .13 \quad-.48$

Reasoning $\quad .16 \quad .47$

$\begin{array}{lll}\text { Other Oriented Reasoning } & -.56 & .06\end{array}$

$\begin{array}{lll}\text { Eigenvalues } & .65 & .48\end{array}$

Warmth

$\begin{array}{lll}\text { Supp/Acknow. Behavior } & .02 & -.22\end{array}$

$\begin{array}{lll}\text { Praise Behavior } & .16 & .43\end{array}$

Supp/Acknow. Feelings $\quad .47 \quad .26$

$\begin{array}{lll}\text { Affection/Comfort } & -.49 & .05\end{array}$

$\begin{array}{lll}\text { Eigenvalues } & .49 & .30\end{array}$ 